\title{
Lactation and body composition responses to fat and protein supplies during the dry period in under-conditioned dairy cows
}

\author{
G. Jaurena*1 and J. M. Moorby† \\ ${ }^{*}$ Cátedra de Nutrición Animal, Departamento de Producción Animal, Facultad de Agronomía, Universidad de Buenos Aires, \\ Ciudad Autónoma de Buenos Aires C1417 DSE, Argentina \\ †Institute of Biology, Environment and Rural Sciences (IBERS), Aberystwyth University, Gogerddan, Aberystwyth, SY23 3EE, United Kingdom
}

\section{ABSTRACT}

An experiment was designed to study the effect of precalving supplementation with protein $(\mathrm{Pr})$ and rumeninert fat $(\mathrm{F})$ on body composition and subsequent milk production and composition. Forty Holstein-Friesian dairy cows were allocated to 1 of 4 dietary treatments in the dry period (DP) based on a first-cut ryegrass silage, with 6 mature (in their third or greater pregnancy) and 4 young (in their second pregnancy) cows per treatment. These were low Pr, low F (silage alone); low $\mathrm{Pr}$, high $\mathrm{F}$ (silage with $10 \%$ rumen-inert fat, mixed on a dry matter basis); high $\mathrm{Pr}$, low $\mathrm{F}$ [silage with $5 \%$ high-protein corn gluten meal (CGM)]; and high Pr, high F (silage with 5\% CGM and 10\% rumen-inert fat). All the diets were individually offered ad libitum and dry matter intake (DMI) was recorded daily during the DP. After calving, all cows received ryegrass silage plus $8 \mathrm{~kg} / \mathrm{d}$ of a commercial dairy concentrate. During the DP, DMI was higher for mature than for young cows. All animals recovered body condition score $(0.13$ units/wk, 1-5 scale), reaching a maximum score of 2.4 some days before calving. Precalving maximum muscle longissimus dorsi (LD) depth was greater for mature $(47.5 \mathrm{~mm})$ than for young cows $(45.7 \mathrm{~mm})$, and milk fat concentration was also higher for mature than for young cows (40.2 and $39.0 \mathrm{~g} / \mathrm{kg}$, respectively). Supplementation with CGM increased maximum LD depth (from 45.9 to $47.6 \mathrm{~mm}$ ), calf birth weight (low $\mathrm{Pr}=$ 43.2 , high $\operatorname{Pr}=46.3 \mathrm{~kg}$ ), and milk crude protein concentration (from 30.8 to $31.6 \mathrm{~g} / \mathrm{kg}$ ). Fat supplementation in the DP of the mature cows increased maximum back fat depth (from 3.6 to $4.5 \mathrm{~mm}$ ), milk yield (low F $=26.3$, high $\mathrm{F}=28.7 \mathrm{~kg} / \mathrm{d}$ ), and $\operatorname{Pr}$ yields (low $\mathrm{F}=$ 837, high $\mathrm{F}=899 \mathrm{~g} / \mathrm{d}$ ). Inclusion of $\mathrm{F}$ in the $\mathrm{DP}$ diets reduced casein concentration in milk at wk 3 of lacta-

Received February 9, 2016.

Accepted October 11, 2016.

${ }^{1}$ Corresponding author: gjaurena@agro.uba.ar tion from 26.3 to $24.5 \mathrm{~g} / \mathrm{kg}$. Milk CP yield was also increased by CGM supplementation when compared within cows receiving $\mathrm{F}$-supplemented silages (low $\mathrm{Pr}$, high $\mathrm{F}=832 \mathrm{~g} / \mathrm{d}$; high $\mathrm{Pr}$, high $\mathrm{F}=877 \mathrm{~g} / \mathrm{d}$ ). It can be concluded that CGM supplementation in the DP increased subsequent milk Pr concentration, but milk Pr yield increased only in those animals also receiving F supplementation. Dry period diet supplementation with $\mathrm{F}$ increased maximum back fat depth and milk and $\mathrm{CP}$ yields in the mature cows, and led to more LD muscle mobilization during early lactation. Secondcalving cows had a lower DMI and milk fat concentration than mature cows.

Key words: dry cow, milk production, milk quality, body composition

\section{INTRODUCTION}

The dry period (DP) of the dairy cow occurs during late gestation, when the highest nutrient demands from the conceptus and mammary tissue development occur (Prior and Laster, 1979; Bell et al., 1995). Many authors have suggested the importance of the DP on the subsequent lactation performance of dairy cows (Grummer, 1998; Drackley, 1999), but many dairy producers still tend to think of the dry cow as having relatively low energy and protein requirements. The metabolic, physiological, and behavioral changes associated with this relatively short period of the lactation cycle suggest a phase of high metabolic activity, and producers should consider the DP as a linking phase between successive lactations, when management aims to prepare the cow to cope with the next lactation. The aim of DP management should be to avoid subsequent metabolic disorders, to support fetal calf growth and mammary gland development, and optimize subsequent milk production and composition without compromising reproductive performance.

Many cows start the dry period under-conditioned, leading to cows calving below the optimum BCS and thereby becoming more susceptible to a variety of health problems (NRC, 2001). Although the need to 
improve the body condition of under-conditioned cows at drying off has been noted by some authors (van Saun and Sniffen, 1996), achievement of a moderate amount of body reserves throughout the late pregnancy period is acknowledged as a key factor to maximize dairy cow productive performance in the subsequent lactation (van Saun and Sniffen, 1996; Studer, 1998; NRC, 2001). Cows that begin lactation with a BCS of less than 2.8 (on a $0-5$ scale) may not be capable of mobilizing enough energy to support maximal milk production (Otto et al., 1991) and may have suboptimal reproductive capabilities (Crowe, 2008). Previous experiments have highlighted the effects of BW gain during the DP, focusing particularly on the consequences of over-conditioning (Fronk et al., 1980), but little attention has been paid to recovery of body reserves by thin cows. Grum et al. (1996) indicated that replenishment of the energy reserves of under-conditioned cows during the DP could increase milk production and decrease the incidence of metabolic disorders during early lactation, but further research of the same group suggested that recovering $\mathrm{BW}$ during the entire $\mathrm{DP}$ could bring about peripartum health problems and impaired postpartum performance, even when animals did not become overconditioned (Douglas et al., 2006).

Nutrition of dairy cows during the final stages of gestation is further complicated because any nutritional imbalance is exacerbated by a typical DMI reduction (Ingvartsen and Andersen, 2000; NRC, 2001) and the fact that overfeeding can promote fetal overgrowth, which can lead to dystocia and other health problems in the cow (Mee, 2008). At the same time, increasing fetal nutrient demands can bring about important maternal body tissue remobilization with undesirable consequences on the cow's postpartum performance (Beever, 2006; Crowe, 2008).

In under-conditioned cows (BCS typically <2), supplying large quantities of dietary energy as carbohydrate (grain) during the DP to improve BCS can lead to risk problems such as fatty liver (Grum et al., 1996). However, supplying energy in the form of fat reduces this risk because the liver is not a lipid depot during positive energy balance (NRC, 2001). In addition, feeds with a high concentrations of fat constrain energy supply to the fetus due to low conceptus access to fatty acids and keto acids (Bell, 1993), and it has been speculated that feeding fat to dry cows could lead to increased fatty acid oxidation and reduced fatty acid esterification in liver metabolism (Grum et al., 1996). According to Grummer (1993), dietary fat could minimize the risk of fatty liver, ketosis, or both by (a) reducing fatty acid mobilization from adipose tissue, (b) alleviating the shortage of fatty acid precursors for mammary triglyceride synthesis, and (c) by sparing glu- cose oxidation by reducing the requirement of NADPH for mammary fatty acid synthesis. In other dietary considerations, supplementation with bypass protein during the DP has shown improvements in milk production and composition (van Saun et al., 1993; Moorby et al., 1996; Moorby et al., 2002a,b), apparently mediated by replenishment of the labile body protein pool.

Our hypothesis was that increasing the fat and protein supply to the dairy cow during the late DP would improve body fat reserves and labile body protein, hence supporting milk production and composition during the early phase of the subsequent lactation. The objective of our study was to examine the effect of precalving dietary protein and rumen-inert fat supply on body composition and subsequent milk production and composition of under-conditioned dry dairy cows.

\section{MATERIALS AND METHODS}

\section{General Design and Management}

To investigate the interactive effects of fat and protein in precalving diets, diets based on first-cut ryegrass silage supplemented with a rumen-inert fat source and a rumen bypass protein source were fed. The fat source was Megalac (Volac International Ltd., Royston UK), a calcium soap of long-chain fatty acids from palm oil, containing $772 \mathrm{~g} / \mathrm{kg}$ of acid hydrolysis ether extract and, according to manufacturer label specifications, supplied $48 \% \mathrm{C} 16: 0,5 \% \mathrm{C} 18: 0,36 \% \mathrm{C} 18: 1$, and 9\% C18:2. The rumen bypass protein source was corn gluten meal.

Forty Holstein-Friesian dairy cows at the Institute of Grassland and Environmental Research Trawsgoed Research Farm (Aberystwyth, UK) were allocated to 1 of 4 diets in a factorial treatment arrangement of rumen-inert fat $(\mathbf{F})$ and protein $(\mathbf{P r})$. The experimental diets were all based on first-cut ryegrass silage and were low-Pr, low-F (Ll), the ryegrass silage only; low-Pr, high-F (Lh), the same silage with $10 \%$ rumeninert fat (mixed on a DM basis); high-Pr, low-F ( Hl), the same silage with $5 \%$ high-protein corn gluten meal (CGM); high-Pr, high-F (Hh), the same silage with $5 \%$ CGM and $10 \%$ rumen-inert fat. Animals were balanced for parity across treatments, with 6 mature (in their third or greater pregnancy) and 4 young (in their second pregnancy) cows per treatment. The average age of the 16 young cows at the start of the experiment was $36( \pm 3.6)$ mo. In the mature group, 11 cows were in their third pregnancy ( $46 \pm 0.7$ mo old), 8 cows in their fourth pregnancy $(58 \pm 0.8$ mo old $)$, and 5 cows in their fifth pregnancy $(71 \pm 1.5$ mo old $)$.

Animals were adapted to the housing and were trained to use Calan gates (American Calan, Northwood, $\mathrm{NH}$ ) over a 2 -wk period before the start of the 
experiment. Experimental diets were offered from 6 wk before the expected calving date and cow measurements were collected from then until wk 20 of lactation. Rations were offered ad libitum (to approximately $10 \%$ refusals) as a TMR at approximately $0900 \mathrm{~h}$ each day. Fresh water was available throughout the day, and mineral and vitamins were added to all TMR according to manufacturer (Richard Keenan UK Ltd., Kenilworth, UK) specifications.

When cows were judged by dairy staff to be about to calve (by changes in behavior and udder volume), they were moved to individual straw pens where they were introduced to the lactation diet. This comprised ad libitum access to ryegrass silage with $4 \mathrm{~kg}$ of fresh matter/d of a dairy concentrate. The composition of the concentrate (per $\mathrm{kg}$ of frozen DM) was 13.5 MJ of ME, $225 \mathrm{~g}$ of $\mathrm{CP}, 225 \mathrm{~g}$ of NDF, $111 \mathrm{~g}$ of ADF, 237 $\mathrm{g}$ of starch, and $54 \mathrm{~g}$ of acid hydrolysis ether extract. After calving, all cows received ad libitum access to the same ryegrass silage together with a daily allocation of concentrate feed. Immediately after calving the fresh matter quantity of concentrate offered to the cows was increased in steps $(4,5,6,7$, and $8 \mathrm{~kg} / \mathrm{d}$ respectively for d 0 to 1,2 to 3,4 to 5,6 to 7 , and $8 \mathrm{~d}$ of lactation), and after the first $8 \mathrm{~d}$ of lactation all cows were offered $8 \mathrm{~kg} / \mathrm{d}$ for the remainder of the experiment.

\section{Feed Sampling and Analysis}

The silage was prepared from a first-cut ryegrassdominated sward ensiled using a silage inoculant (Ecosyl Bio-Products Ltd., Royston, UK) in 2 adjacent bunkers. Representative samples of all feeds (silage, CGM, Megalac, TMR, and concentrates) were collected weekly, pooled to provide 2 samples per month, and stored frozen until analyzed. Fresh (thawed) samples of silage were analyzed for DM (by freeze-drying to constant weight), $\mathrm{pH}$, ammonia, and lactic, acetic, propionic, and butyric acids. All other analyses of silage or concentrate samples were conducted on freeze-dried material.

Aqueous extracts of silage samples were prepared by mixing $20 \mathrm{~g}$ of thawed silage with $100 \mathrm{~mL}$ of distilled water and kept at $4^{\circ} \mathrm{C}$ overnight; $\mathrm{pH}$ was measured in the solution after allowing it to equilibrate with room temperature for $30 \mathrm{~min}$. Samples were then filtered through fast-flow filter paper and aliquots of the filtrate were pipetted into microcentrifuge tubes and frozen for later analysis. Volatile fatty acid concentrations were determined by GC (Zhu et al., 1996). Lactic acid concentration was determined by a spectrophotometric technique using a kit specific for L-lactic acid (procedure 826-UV; Sigma-Aldrich Co. Ltd., Dorset, UK), followed by a second determination on the same sample using the specific D-lactic acid dehydrogenase (Sigma-Aldrich product L-9636). Ammonia-N concentration of silage was determined by the reaction of ammonia with salicylate and dichloroisocyanurate in alkaline solution to produce a substituted indophenol blue. The color was read in a ChemLab system 4 colorimeter (ChemLab Instruments Ltd., Great Dunmow, Essex, UK) linked to a continuous flow analysis system. Analysis of feed concentrations of $\mathrm{OM}, \mathrm{CP}, \mathrm{NDF}, \mathrm{ADF}$, water-soluble carbohydrates, ether extract, and acid hydrolysis ether extract were completed as described by Dewhurst et al. (2000). Feed starch concentrations were determined as described by Moorby et al. (2016).

\section{Measurements and Sample Collection on Animals}

Cows were individually offered their allocated diets on a daily basis throughout the experiment using Calan gates. Feed refusals were removed and weighed on Mondays, Wednesdays, and Fridays to estimate DMI on a daily basis. Dry matter intake was initially calculated on an oven $\mathrm{DM}$ basis (drying at $100^{\circ} \mathrm{C}$ overnight) and later corrected to a frozen DM basis (freeze-drying to a constant weight).

Animal BW, BCS, and depths of longissimus dorsi (LD) and back fat were measured after morning milking from 6 wk before anticipated calving (i.e., wk -6) until wk 20 of lactation. Body condition score, LD, and back fat were assessed weekly from wk -6 to +8 of lactation, and once every 4 wk from wk 9 of lactation until the end of the experiment at wk 20 of lactation. Around calving ( -10 to $+10 \mathrm{~d}$ of parturition) all these measurements were performed more frequently, on each Monday, Wednesday, and Friday. After calving, BW was automatically recorded daily after each morning milking and averaged on a weekly basis. Body condition score was assessed by the same operator throughout the experiment using a 0 to 5 scale (Mulvany, 1977). Longissimus dorsi and back fat depths were measured perpendicular to the skin using real-time ultrasound imaging at the fifth lumbar process (Concept $\backslash \mathrm{MCV}$ Ultrasound scanner, Dynamic Imaging Ltd., Livingstone, UK). Udder volume was estimated assuming the udder to be spherical $\left(\mathrm{cm}^{3}=4 / 3 \times \pi \times \mathrm{r}^{3}\right)$, as described in Jaurena (2003).

Milk yields were measured and recorded automatically at each milking and samples were taken until wk 20 of lactation; milk samples were collected from each cow at 2 consecutive milkings weekly and analyzed for fat, protein, and lactose by infrared milk analysis (National Milk Records Central Laboratory, Somerset, UK). Gross energy of the milk samples was estimated by the formulae of Tyrrell and Reid (1965; quoted in AFRC, 1993) using milk fat, protein, and lactose con- 
tents for the current lactation data, and the formulae based on milk fat and protein contents for the previous lactation data.

At wk 3 and 8 of lactation, an extra sample of milk was taken and analyzed for milk CP fractions. Milk $\mathrm{CP}$ (total $\mathrm{N} \times 6.38$ ) was estimated in duplicate by Kjeldahl analysis, and milk protein fractions were separated according to the International Dairy Federation Standard (FIL-IDF, 1964) into true protein (TPr), casein N, NPN, and whey proteins by difference. Milk urea concentration was estimated by a Sigma-Aldrich kit for urea-N determination (No. 640), and read spectrophotometrically at $570 \mathrm{~nm}$.

\section{Statistical Analysis}

Preliminary analysis of results showed an important interaction of the dietary factors under study with animal maturity (young vs. mature cows). Consequently, data were analyzed in a factorial arrangement $(2 \times$ $2 \times 2$ ) of maturity, Pr, and F supplementation in a complete randomized design. Statistical analyses were carried out using GenStat (5th edition; Genstat Committee, 2000) and, unless otherwise stated, fitted to the following model:

$$
\begin{aligned}
Y_{i j k}= & \mu+\operatorname{Cov}+M+\operatorname{Pr}+F+M \times \operatorname{Pr}+M \\
& \times F+\operatorname{Pr} \times F+M \times \operatorname{Pr} \times F+\varepsilon,
\end{aligned}
$$

where $Y_{i j k}$ is the response variable value; $\mu$ is the grand mean; Cov is the covariable; $M$ is the maturity; and $\varepsilon$ is the random error estimated by the residual of the model.

The DMI data from the DP were fitted to an exponential model $\left[y=a+b \times\left(1-b^{k \times d}\right)\right.$, where $d$ is days precalving, and $a, b$, and $k$ are model constants] using the Genstat Standard Curves procedure (GenStat Committee, 2000). Starting BW measurements and BW measured at the first week of lactation were used as covariates for intake data for pre- and postcalving periods, respectively, to allow for differences in cow body size. Pre- and postcalving weekly DMI means were studied by linear correlation analysis.

Maximum values before calving and minimum values after calving for BW, BCS, back fat, and $\mathrm{LD}$ were analyzed by analysis of covariance using the first measurement of each variable in the DP as the covariate. Analysis of the time (in weeks) between maximum precalving $\mathrm{BCS}, \mathrm{BW}, \mathrm{LD}$, and back fat records and calving was carried out using a complete randomized block design (blocking by cow). A similar analysis was completed for the interval between calving and minimum record postpartum.
Calf birth weights were analyzed by using calf sex as an additional factor in the model. Milk composition and yield (volume and components) were analyzed using each animal's previous lactation records as covariates. Milk protein fraction concentrations and yields at wk 3 and 8 of lactation were analyzed by a model including previous lactation $\mathrm{CP}$ concentrations or yields as covariates.

Health events were analyzed by logistic regression (GenStat Committee, 2000). Health events including retained placenta, reproductive tract infections, cystic ovary, postpartum anestrus, and hormone treatment to resume reproductive cycling were grouped together and analyzed as reproduction problems. Incidents of general lameness, sole ulcers, and interdigital dermatitis were grouped and analyzed as feet problems.

\section{RESULTS}

All cows were dried off 8 wk before their expected calving date and calved between September 1 and October 19, 1999. The average time on precalving treatment was 39 to $44 \mathrm{~d}$.

Five cows were diagnosed and successfully treated for mastitis within the first week of calving; 1 cow was treated for milk fever and successfully recovered after calving. Crude protein fraction data collected from the mastitic cows [which were on treatments Ll (1), Lh (2), Hl (1), and Hh (1)] were excluded from subsequent statistical analyses. One cow in the mature-Hl treatment group calved twins. One cow (treatment Lh) did not adapt to using the Calan gates and could not be replaced with a suitable animal; therefore, only the remaining 39 animals were used for the final analyses.

Although the study of health problems was beyond the scope of this work due to the limited number of animals, a higher incidence of reproductive problems was detected in those cows receiving $\mathrm{F}$ supplementation $(P$ $\leq 0.05 ; \mathrm{Ll}=1, \mathrm{Hl}=1, \mathrm{Lh}=6 ; \mathrm{Hh}=3$ ). Furthermore, an $\mathrm{F} \times \mathrm{Pr}$ interaction $(P \leq 0.05)$ occurred for total health incidents $(\mathrm{Ll}=2 ; \mathrm{Hl}=4 ; \mathrm{Lh}=8 ; \mathrm{Hh}=7)$. No differences were detected for the incidence of calving problems, mastitis, or milk fever.

\section{Feed Characteristics and Intake}

Feed characteristics were homogeneous throughout the experiment (Tables 1 and 2). Although the CP concentration of $\mathrm{Hh}$ ration was significantly (Tukey test, $P<0.05)$ higher than that of diet Lh, inclusion of CGM with ryegrass silage did not lead to a statistically significant difference (Tukey test, $P>0.05 ; \mathrm{Hl}$ vs. Ll ration). Ether extract concentrations were similar for 
Table 1. Mean chemical composition of the diets used during the precalving period and the ryegrass silage offered after calving (in $\mathrm{g} / \mathrm{kg}$ of DM, unless stated otherwise)

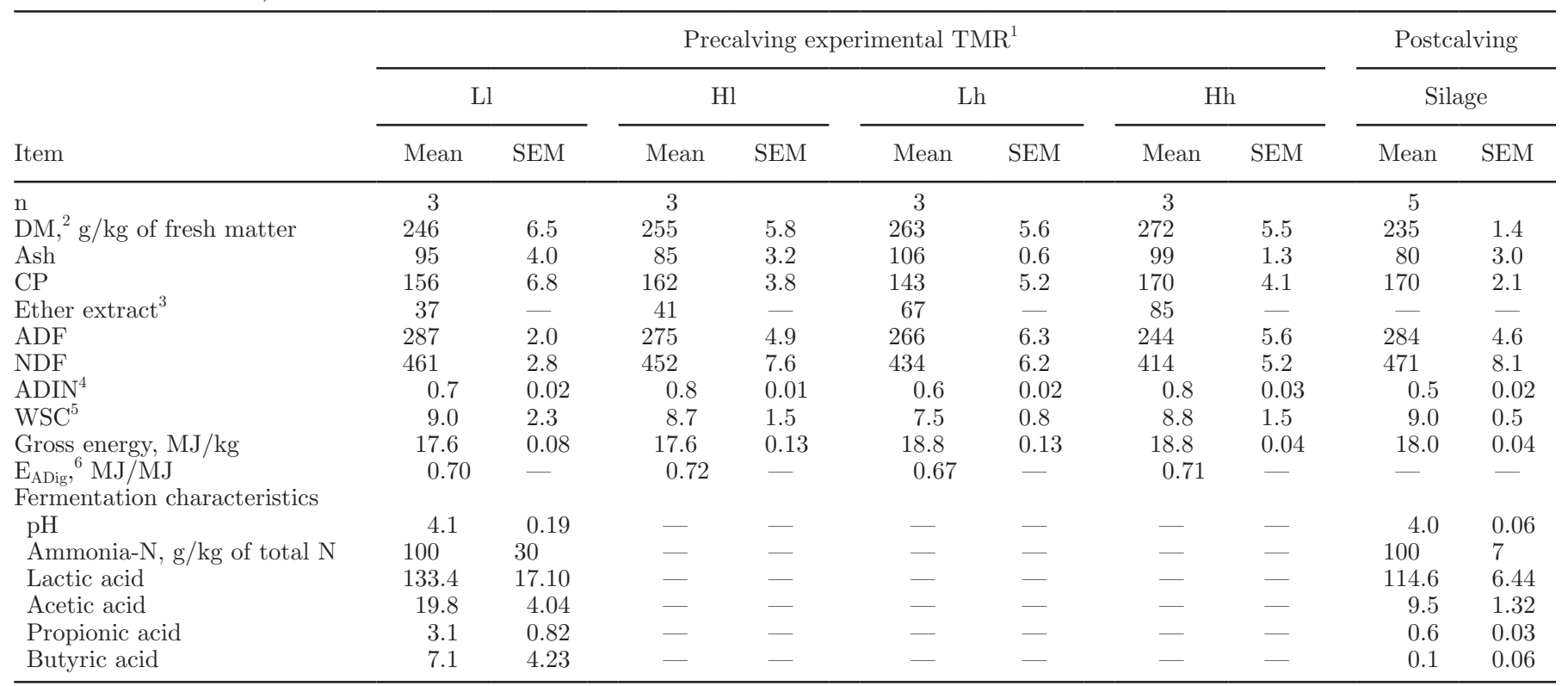

${ }^{1} \mathrm{Ll}=$ low-protein, low-fat ryegrass silage; $\mathrm{Lh}=$ low-protein, high-fat; $\mathrm{Hl}=$ high-protein, low-fat; Hh = high-protein, high-fat.

${ }^{2}$ Frozen dry matter.

${ }^{3}$ From samples collected for in vivo experiments reported by Jaurena (2003).

${ }^{4}$ Acid detergent insoluble N.

${ }^{5}$ Water-soluble carbohydrates.

${ }^{6}$ Apparent digestibility of energy.

$\mathrm{Ll}$ and $\mathrm{Hl}$ rations and were considerably lower than concentrations in $\mathrm{Lh}$ and $\mathrm{Hh}$ rations.

Analysis of intake data showed that mature cows ate more than their younger counterparts (means of 13.2 and $11.1 \mathrm{~kg} / \mathrm{d}$, respectively; $\mathrm{SEM}=0.27 ; P<0.001)$ in correspondence with their BW; when adjusted for initial BW, however, DMI increased from 11.8 to 13.3 $\mathrm{kg} / \mathrm{d}$ within the high-F treatments in association with CGM supplementation $\left(P_{F \times P r}<0.05\right.$; Table 3$)$. This increase was particularly large for the mature cows offered the high-F rations (mature-Hh; $P_{M \times F \times P r}<$ $0.05)$, as they ate $26 \%$ more than those offered the Lh treatment $(P \leq 0.05)$. During the DP, DMI tended to decrease between 3 and $17 \mathrm{~d}$ before calving (Figure 1). In addition to this reduction, analysis of DMI measurements made before the animals were dried off (data not shown) indicated that the DMI of $60 \%$ (23) of the animals had started to decrease before the dry period

Table 2. Mean chemical composition of concentrates used before and after calving (in $\mathrm{g} / \mathrm{kg}$ of frozen DM, unless stated otherwise)

\begin{tabular}{|c|c|c|c|c|c|c|}
\hline \multirow[b]{2}{*}{ Item } & \multicolumn{2}{|c|}{ Rumen inert fat ${ }^{1}$} & \multicolumn{2}{|c|}{ Corn gluten meal } & \multicolumn{2}{|c|}{ Dairy concentrate } \\
\hline & Mean & SEM & Mean & SEM & Mean & SEM \\
\hline $\mathrm{N}$ & 3 & & 3 & & 7 & \\
\hline DM, $\mathrm{g} / \mathrm{kg}$ of fresh matter & $980^{2}$ & - & 905 & 0.7 & 897 & 4.9 \\
\hline Ash & 242 & 6.8 & 24 & 9.4 & 82 & 1.8 \\
\hline $\mathrm{CP}$ & 0.7 & 0.51 & 624 & 2.9 & 225 & 4.0 \\
\hline NDF & - & - & - & - & 225 & 7.0 \\
\hline $\mathrm{ADF}$ & - & - & - & - & 111 & 4.5 \\
\hline Water-soluble carbohydrates & - & - & 3 & 0.0 & 88 & 2.7 \\
\hline Neutral cellulase gamanase digestibility & - & - & 951 & 12.8 & - & - \\
\hline Starch & - & - & 198 & 9.0 & 237 & 13.3 \\
\hline Acid hydrolysis ether extract & 772 & 6.7 & 83 & 0.3 & 54 & 2.7 \\
\hline Gross energy, MJ/kg & 32.1 & 0.07 & 22.8 & 0.06 & 18.0 & 0.09 \\
\hline
\end{tabular}

${ }^{1}$ Megalac (Volac International Ltd., Royston, UK).

${ }^{2}$ As indicated by the manufacturer. 
Table 3. Mean treatment effects on precalving DMI and measurements of BCS, BW, and loin depths of longissimus dorsi (LD) and back fat of cows offered diets $\mathrm{Hh}, \mathrm{Hl}, \mathrm{Lh}$, and $\mathrm{Ll}^{1}$ during the dry period.

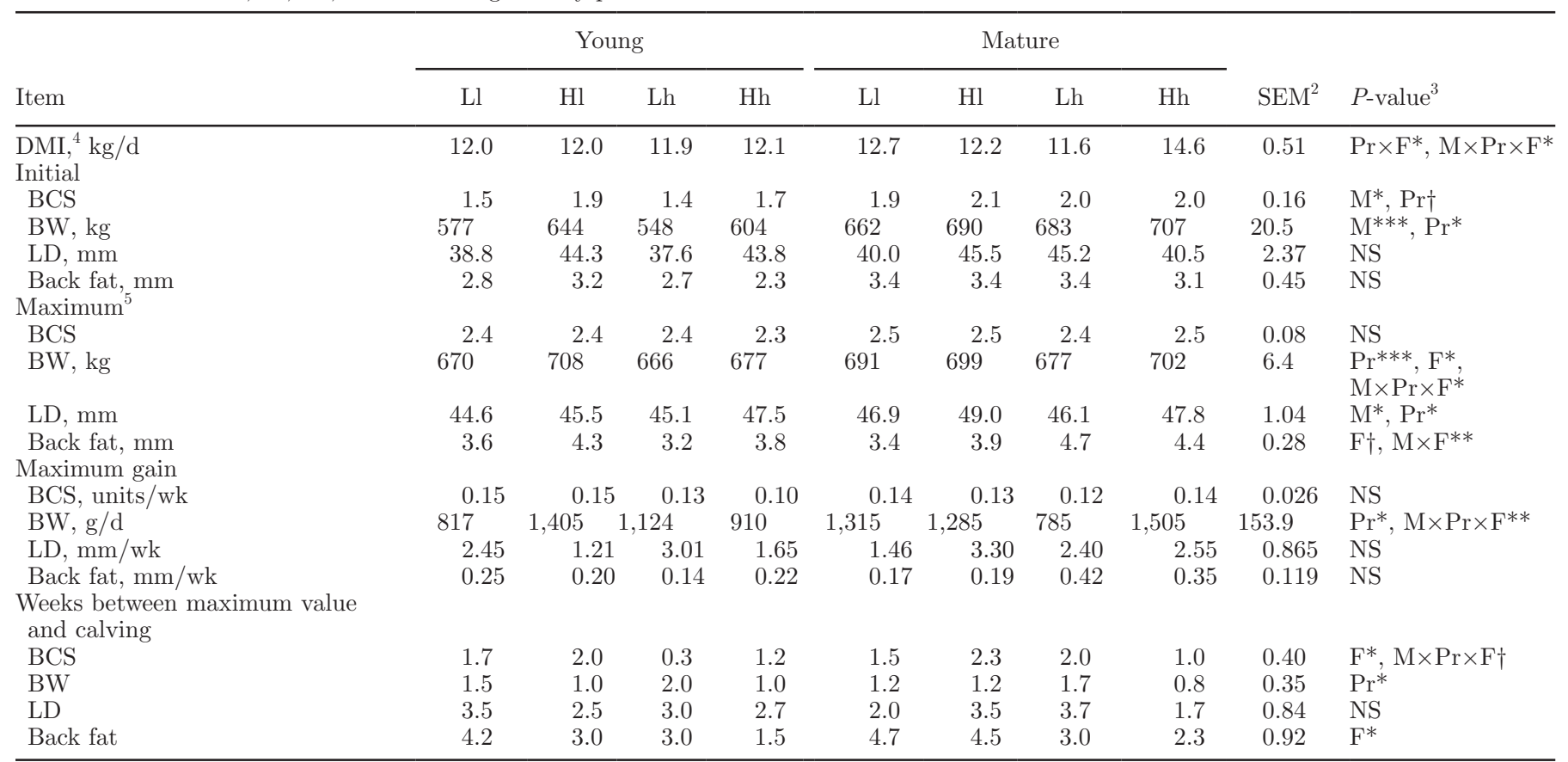

${ }^{1} \mathrm{Ll}=$ low-protein, low-fat ryegrass silage; $\mathrm{Lh}=$ low-protein, high-fat; $\mathrm{Hl}=$ high-protein, low-fat; Hh = high-protein, high-fat.

${ }^{2}$ Standard error of the mean for $\mathrm{n}=6$.

${ }^{3} \mathrm{M}=$ maturity; $\mathrm{Pr}=$ protein; $\mathrm{F}=$ fat.

${ }^{4}$ Covariable (initial BW) corrected means.

${ }^{5}$ Covariable (first homologous data recorded) corrected means.

$\dagger P \leq 0.10 ;{ }^{*} P \leq 0.05 ;{ }^{* *} P \leq 0.01 ; * * * P \leq 0.001$.

started, and this is seen in the overall intake patterns of groups young-Lh, mature-Hl, and mature-Hh in Figure 1. After calving, mature cows consumed more DM (mean of $18.2 \mathrm{~kg} / \mathrm{d}$ ) than the young cows $(16.7 \mathrm{~kg} / \mathrm{d} ; P$ $<0.001$, model without covariate) but we found no differences in covariate-adjusted DMI, with grand means for the first $20 \mathrm{wk}$ of lactation for total DMI, silage DMI, and proportion of concentrate of $17.6 \mathrm{~kg} / \mathrm{d}, 10.6$ $\mathrm{kg} / \mathrm{d}$, and $40 \%$, respectively.

\section{Body Composition Characteristics}

Cows started the experiment with mean actual BCS of $1.6(\mathrm{SEM}=0.10)$ and $2.0(\mathrm{SEM}=0.08)$, and $\mathrm{BW}$ of $593(\mathrm{SEM}=10.2)$ and $686 \mathrm{~kg}(\mathrm{SEM}=12.5)$ for young and mature groups, respectively $(P<0.01$; model without covariable; Table 3$)$. Mean maximum LD depth was greater for the mature group $(46.4 \mathrm{~mm})$ than for the young group ( $45.6 \mathrm{~mm} ; P=0.047)$, and increased with CGM supplementation from 45.6 to 47.4 $\mathrm{mm}(\mathrm{SEM}=0.64 ; P=0.06)$. Supplementation with $F$ increased maximum back fat thickness only in the mature animals (mature-low $\mathrm{F}=3.6 \mathrm{~mm}$, mature-high
$\left.\mathrm{F}=4.5 \mathrm{~mm} ; \mathrm{SEM}=0.20, P_{F}<0.05\right)$ and reduced the time from maximum BCS $\left(P_{F}=0.039\right)$ and back fat $\left(P_{F}=0.024\right)$ to calving. Body tissue mobilization started before calving, as shown by Figures 2 and 3, and time between the maximum BCS, BW, LD, and back fat and calving are presented in Table 3. The maxima of the various variables differed in time: back fat $(3.45 \mathrm{wk})>\mathrm{LD}(2.87 \mathrm{wk})>\operatorname{BCS}(1.63 \mathrm{wk})>\mathrm{BW}$ (1.29 wk; back fat and LD differed significantly from BCS and BW, $P<0.05)$.

The minimum LD was recorded at 5.5 wk postcalving (grand mean for all treatments; Table 4), despite differences due to maturity (mature $>$ young cows; $P_{M}<$ 0.05 ), protein inclusion (high $\operatorname{Pr}>$ low $\operatorname{Pr} ; P=0.045$ ), and F supplementation (low F $>$ high F; $P_{F}=0.007$ ). Postpartum LD loss was greater for those cows receiving rations with $\mathrm{F}$ during the DP $(P=0.042)$. We also noted significant differences in the time between calving and minima of the different variables studied (i.e., BW, $4.2 \mathrm{wk}$; LD, $5.6 \mathrm{wk}$; BCS, $6.1 \mathrm{wk}$; and back fat, $11.1 \mathrm{wk} ; P<0.001)$. No differences among treatments were observed in estimated udder volume at calving $($ grand mean $=38.5 \mathrm{~L}, \mathrm{SEM}=1.53 ; P>0.10)$. 

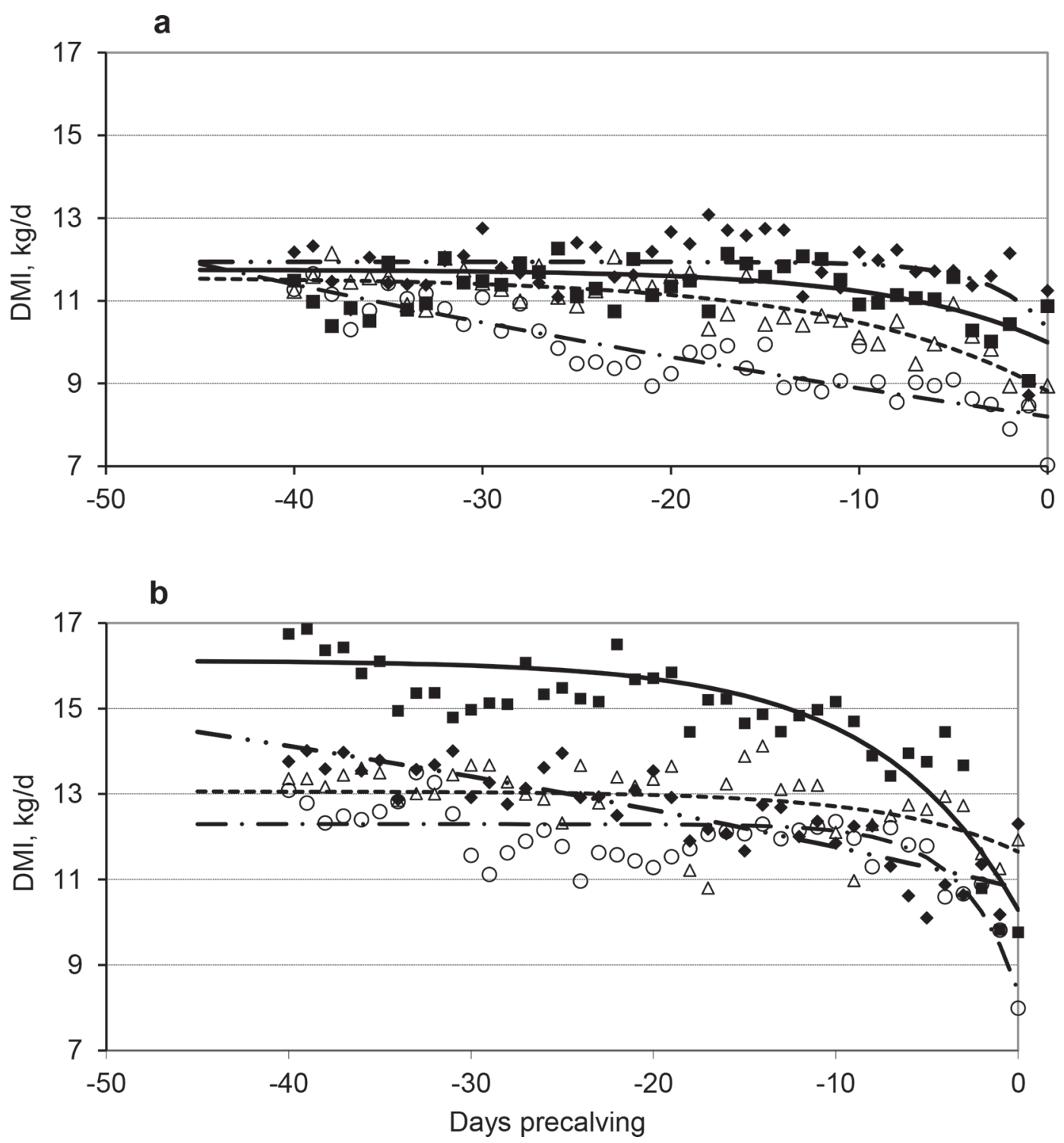

Figure 1. Daily DMI of young $\left(\mathrm{a} ; \mathrm{R}^{2}=0.69 ; P<0.001\right)$ and mature $\left(\mathrm{b} ; \mathrm{R}^{2}=0.80 ; P<0.001\right)$ cows fed the experimental diets during the dry period. $\mathrm{Hh}=$ high-protein, high-fat $(\boldsymbol{\square}$, solid line); $\mathrm{Hl}=$ high-protein, low-fat ( $\bullet$, line with long dashes and 2 dots); Lh $=$ low-protein, high-fat $(\bigcirc$; line with long dashes and a single dot); $\mathrm{Ll}=$ low-protein, low-fat $(\Delta ;$ dashed line). Scatter symbols correspond to data and lines to the fitted exponential model DMI $(\mathrm{kg})=a+b \times\left(1-e^{-k \times d}\right)$, where $d$ is days before calving and $a, b$, and $k$ are model constants, and $e$ is the base of natural logarithms.

\section{Calf Birth Weights, Milk Composition, and Yield}

Male calf birth weights were higher than those of females calves (47.0 and $42.6 \mathrm{~kg}$, respectively; SEM = $1.25 \mathrm{~kg}, P=0.014)$, and cows receiving Pr supplementation delivered heavier calves than their nonsupplemented counterparts (low $\mathrm{Pr}=43.2$, high $\mathrm{Pr}=46.3$, $\mathrm{SEM}=1.10 \mathrm{~kg}, P=0.048)$. We found no difference in birth weights of calves from young and mature cows. Colostrum CP concentration averaged $141 \mathrm{~g} / \mathrm{kg}$ and did not show any differences among treatments $(P>$ $0.05)$.
Cow maturity was associated with higher milk fat concentrations (mature cows $=40.2$; young cows $=$ $39.0, \mathrm{SEM}=0.49 \mathrm{~g} / \mathrm{kg} ; P_{M}=0.09$; Table 5$)$, and milk $\left(P_{M \times F}<0.10\right)$ and protein yields $\left(P_{M \times F}=0.01\right)$ of F-supplemented cows. Inclusion of CGM in the DP diet tended to increase milk protein concentration (between 1 and $1.5 \mathrm{~g}$ of $\left.\mathrm{CP} / \mathrm{kg}, P_{P}=0.086\right)$, particularly during the first month postpartum, but milk protein yield only increased when CGM was included with the Fsupplemented silages $(P<0.07)$; within the low-F DP treatments the average milk protein yield was $839 \mathrm{~g} / \mathrm{d}$ $(P>0.10)$. 
Analysis of milk protein fractions showed lower casein $\mathrm{N}$ at wk 3 of lactation after inclusion of $\mathrm{F}$ in the precalving diet (low $\mathrm{F}=26.3$, high $\mathrm{F}=24.5 \mathrm{~g} / \mathrm{kg} ; P_{F}$ $=0.002$; Table 6 ); and a maturity $\times \mathrm{F}$ interaction for milk NPN and urea (which was deemed meaningless due to the lack of difference when tested by least significant difference, $P=0.05$ ). At wk 8 of lactation, the only experimental effect on milk composition was on urea concentration $\left(P_{M \times P r \times F}=0.001\right)$ associated with CGM inclusion $(0.33 \mathrm{~g} / \mathrm{kg}$ for the young-Hh group vs. $0.27 \mathrm{~g} / \mathrm{kg}$ for the young-Lh group; $P<0.05)$ and within the mature group (mature- $\mathrm{Ll}=0.25 \mathrm{~g} / \mathrm{kg}$, mature- $\mathrm{Hl}$ $=0.30 \mathrm{~g} / \mathrm{kg} ; P<0.05)$. Otherwise, the overall mean milk urea concentration for young cows on low-F diets was $0.30 \mathrm{~g} / \mathrm{kg}$, and for mature cows on high-F diets was $0.24 \mathrm{~g} / \mathrm{kg}$. The other protein fraction grand means were $\mathrm{CP}=32.9 \mathrm{~g} / \mathrm{kg} ; \mathrm{TPr}=30.1 \mathrm{~g} / \mathrm{kg} ;$ casein $=23.4 \mathrm{~g} / \mathrm{kg}$; and whey proteins $=6.7 \mathrm{~g} / \mathrm{kg}$.

Milk yield, CP, TPr, casein N, and NPN yields all increased in mature cows with inclusion of dietary $\mathrm{F}$ in the DP $\left(P_{M \times F}<0.05\right.$; Table 7$)$. The $\mathrm{F} \times \operatorname{Pr}$ interaction effect was significant for $\mathrm{CP}$, TPr, and casein $\mathrm{N}$ yields.
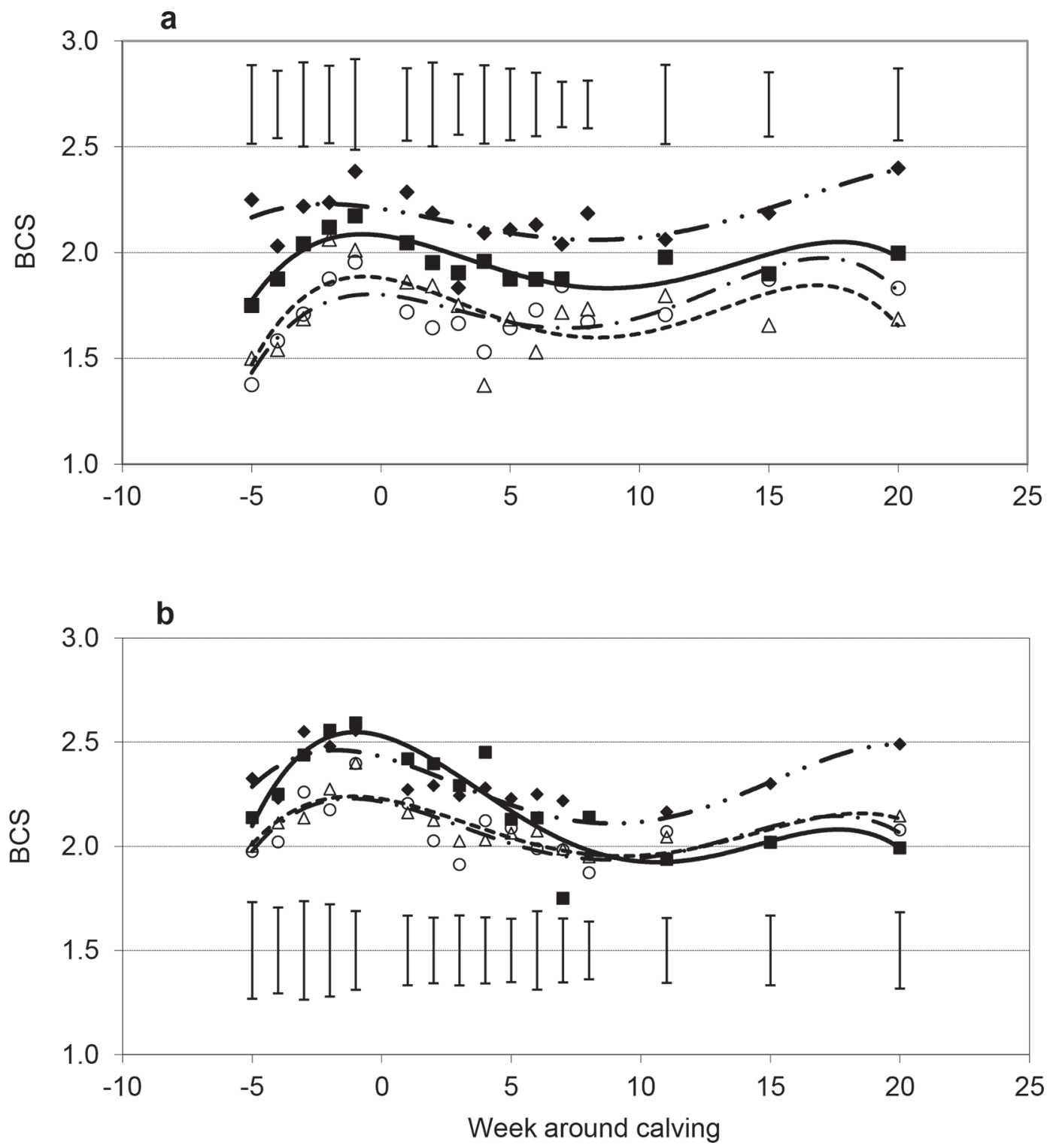

Figure 2. Body condition score of young (a) and mature (b) cows fed the experimental diets during the precalving period. Hh $=$ high-protein, high-fat ( $\mathbf{\square}$, solid line); $\mathrm{Hl}=$ high-protein, low-fat ( $\bullet$, line with long dashes and 2 dots); Lh = low-protein, high-fat ( $\bigcirc$; line with long dashes and a single dot); $\mathrm{Ll}=$ low-protein, low-fat $(\Delta ;$ dashed line). Markers represent treatment means; lines are fitted fourth-degree polynomials. Vertical bars equal 1 pooled SD. 

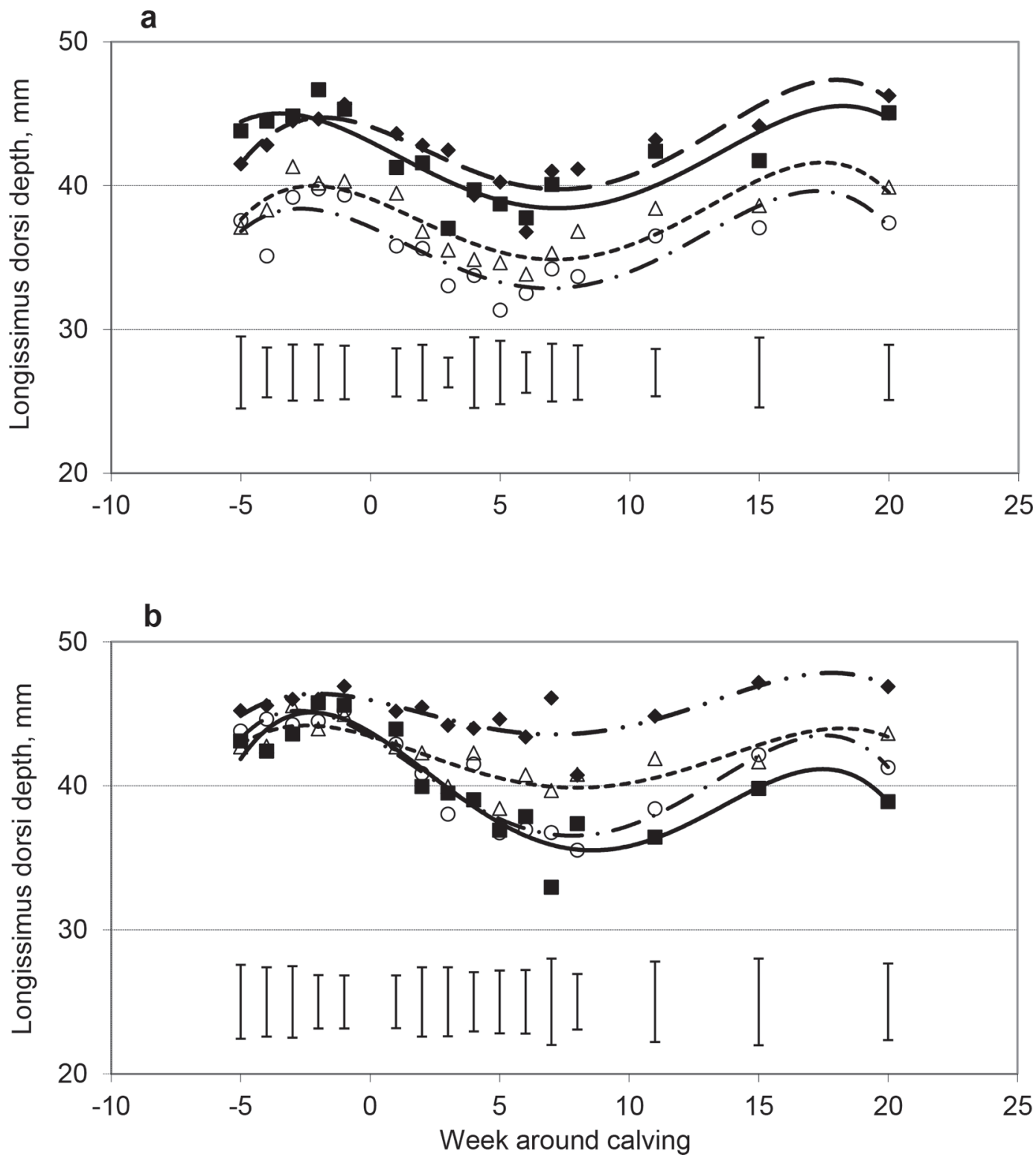

Figure 3. Longissimus dorsi depth of young (a) and mature (b) cows fed the experimental diets during the precalving period. Hh $=$ highprotein, high-fat $(\mathbf{\square}$, solid line); $\mathrm{Hl}=$ high-protein, low-fat $(\bullet$, line with long dashes and 2 dots); Lh $=$ low-protein, high-fat $(\bigcirc$; line with long dashes and a single dot); $\mathrm{Ll}=$ low-protein, low-fat $(\Delta$; dashed line). Markers represent treatment means; lines are fitted fourth-degree polynomial. Vertical bars equal 1 pooled SD.

Within the low-F treatments this difference was probably brought about by a depression in casein $\mathrm{N}$ yields with $\mathrm{Pr}$ supplementation $(\mathrm{Ll}=828, \mathrm{Hl}=717 \mathrm{~g} / \mathrm{d}, P$ $<0.05)$. At wk 8 of lactation the inclusion of $\mathrm{F}$ in the DP diet led to increased milk yields only in the mature animals $\left(P_{M \times F} \leq 0.01\right)$. Milk urea yields within the young animals $\left(P_{M \times P r \times F}=0.029\right)$ showed significant differences between $\mathrm{Lh}(6.9 \mathrm{~g} / \mathrm{d})$ and $\mathrm{Hh}(9.1 \mathrm{~g} / \mathrm{d} ; P<$ 0.05) DP groups.

\section{DISCUSSION}

The lowest incidence of health problems was associated with cows offered ryegrass silage alone in the DP (i.e., Ll). Although the number of animals was too small to draw definite conclusions, the higher incidence of reproductive and health problems among animals that received additional dietary fat during the DP did not agree with the beneficial effects hypothesized by some 
Table 4. Mean treatment effects on postcalving measurements of BCS, BW, and loin depths of longissimus dorsi (LD) and back fat of cows offered diets $\mathrm{Hh}, \mathrm{Hl}, \mathrm{Lh}$, and $\mathrm{Ll}^{1}$ during the dry period

\begin{tabular}{|c|c|c|c|c|c|c|c|c|c|}
\hline \multirow[b]{2}{*}{ Item } & \multicolumn{3}{|c|}{ Maturity $^{2}$} & \multicolumn{2}{|c|}{ Protein } & \multicolumn{3}{|c|}{ Fat } & \multirow[b]{2}{*}{$P$-value ${ }^{5}$} \\
\hline & $\mathrm{Y}$ & M & $\mathrm{SEM}^{3}$ & Low & High & Low & High & $\mathrm{SEM}^{4}$ & \\
\hline $\mathrm{n}$ & 16 & 24 & - & 20 & 20 & 20 & 20 & - & \\
\hline \multicolumn{10}{|l|}{ Minimum $^{6}$} \\
\hline BCS & 1.8 & 1.8 & 0.06 & 1.7 & 1.9 & 1.8 & 1.8 & 0.06 & $\mathrm{Cov}^{* * *}$ \\
\hline $\mathrm{BW}, \mathrm{g} / \mathrm{d}$ & 569 & 583 & 9.0 & 569 & 586 & 581 & 574 & 6.6 & $\mathrm{Cov}^{* * *}$ \\
\hline $\mathrm{LD}, \mathrm{mm}$ & 34 & 37 & 0.6 & 35 & 37 & 37 & 34 & 0.7 & $\mathrm{Cov}^{* * *}, \mathrm{M}^{*}, \mathrm{Pr}^{*}, \mathrm{~F}^{* *}$ \\
\hline Back fat, mm & 1.1 & 1.5 & 0.14 & 1.3 & 1.4 & 1.4 & 1.3 & 0.14 & $\mathrm{M} \dagger$ \\
\hline \multicolumn{10}{|l|}{ Postpartum loss } \\
\hline BCS, units/wk & 0.10 & 0.08 & 0.010 & 0.08 & 0.09 & 0.10 & 0.08 & 0.011 & NS \\
\hline $\mathrm{BW}, \mathrm{g} / \mathrm{d}$ & 1,213 & 1,107 & 160 & 1,223 & 1,076 & 1,210 & 1,090 & 175 & $\mathrm{M} \times \operatorname{Pr}^{7}$ \\
\hline $\mathrm{LD}, \mathrm{mm} / \mathrm{wk}$ & 1.5 & 1.3 & 0.12 & 1.6 & 1.2 & 1.2 & 1.6 & 0.14 & $\operatorname{Pr} \dagger, \mathrm{F}^{*}, \mathrm{M} \times \operatorname{Pr}^{* 8}$ \\
\hline Back fat, mm/wk & 0.14 & 0.20 & 0.036 & 0.21 & 0.14 & 0.16 & 0.19 & 0.039 & $\mathrm{NS}^{8}$ \\
\hline \multicolumn{10}{|c|}{$\begin{array}{l}\text { Weeks between calving and } \\
\text { minimum } \\
\text { value }\end{array}$} \\
\hline $\mathrm{BCS}$ & 5.6 & 6.6 & 0.91 & 5.7 & 6.6 & 5.5 & 6.9 & 1.0 & NS \\
\hline BW & 3.3 & 4.7 & 0.78 & 3.7 & 4.6 & 3.6 & 4.7 & 0.86 & $\mathrm{NS}^{9}$ \\
\hline LD & 4.9 & 6.0 & 0.45 & 5.0 & 6.0 & 5.5 & 5.5 & 0.49 & NS \\
\hline Back fat & 12.6 & 10.0 & 1.21 & 9.6 & 12.4 & 11.7 & 10.3 & 1.33 & $\mathrm{M} \times \operatorname{Pr} * * 10$ \\
\hline
\end{tabular}

${ }^{1} \mathrm{Ll}=$ low-protein, low-fat ryegrass silage; $\mathrm{Lh}=$ low-protein, high-fat; $\mathrm{Hl}=$ high-protein, low-fat; Hh = high-protein, high-fat.

${ }^{2} \mathrm{Y}=$ young cows; $\mathrm{M}=$ mature cows

${ }^{3}$ Standard error of the mean for $\mathrm{n}=24$.

${ }^{4}$ The same SEM for Pr and F factors.

${ }^{5} \mathrm{Cov}=$ covariate; $\mathrm{M}=$ maturity; $\mathrm{Pr}=$ protein; $\mathrm{F}=$ fat.

${ }^{6}$ Statistical model with covariate of first homologous data recorded during the dry period.

${ }^{7} \mathrm{M} \times \operatorname{Pr}$ for $\mathrm{BW}$ loss $=\mathrm{M}$-Low Pr $=1,366, \mathrm{M}$-High Pr $=849, \mathrm{LSD}(5 \%)=656$; Y-Low Pr $=1010, \mathrm{Y}-\operatorname{High} \operatorname{Pr}=1,417, \mathrm{LSD}(5 \%)=803 \mathrm{~g} / \mathrm{d}$. ${ }^{8} \mathrm{M} \times \operatorname{Pr}$ for LD loss $=$ M-Low $\operatorname{Pr}=1.7, \mathrm{M}-$ High $\operatorname{Pr}=1.0$, LSD $(5 \%)=0.51$; Y-Low $\operatorname{Pr}=1.4$, Y-High Pr $=1.6, \mathrm{LSD}(5 \%)=0.63 \mathrm{~mm} / \mathrm{d}$

${ }^{9}$ Failed Bartlett's test.

${ }^{10} \mathrm{M} \times \mathrm{Pr}$ for weeks since calving to back fat minimum $=\mathrm{M}$-Low $\mathrm{Pr}=6.5, \mathrm{M}$-High $\mathrm{Pr}=13.5, \mathrm{LSD}(5 \%)=4.9 ; \mathrm{Y}$-Low Pr $=14.2, \mathrm{Y}$-High Pr $=10.9, \operatorname{LSD}(5 \%)=6.0 \mathrm{wk}$.

$\dagger P \leq 0.10 ;{ }^{*} P \leq 0.05 ;{ }^{* *} P \leq 0.01 ; * * * P \leq 0.001$

Table 5. Mean treatment effects on daily milk yield, composition, and component yields of the first $20 \mathrm{wk}$ of lactation of cows fed with $\mathrm{Ll}, \mathrm{Lh}, \mathrm{Hl}$, and $\mathrm{Hh}_{\text {diets }}{ }^{1}$ during the precalving period (values are covariate-adjusted means for the $\mathrm{M} \times \mathrm{F}$ interaction $)^{2}$

\begin{tabular}{|c|c|c|c|c|c|c|c|}
\hline \multirow[b]{2}{*}{ Item } & \multicolumn{3}{|c|}{ Young } & \multicolumn{3}{|c|}{ Mature } & \multirow[b]{2}{*}{$P$-value ${ }^{3}$} \\
\hline & Low fat & High fat & SEM & Low fat & High fat & SEM & \\
\hline $\mathrm{n}$ & 8 & 74 & & 114 & 12 & & \\
\hline Yield, kg/d & 27.5 & 26.3 & 1.21 & 26.3 & 28.7 & 0.99 & $\mathrm{M} \times \mathrm{F} \dagger$ \\
\hline Fat, g/d & 1,038 & 1,036 & 43.4 & 1,084 & 1,128 & 35.4 & $\operatorname{Cov}^{\dagger}$ \\
\hline Protein, g/d & 841 & 788 & 24.9 & 837 & 899 & 20.3 & $\mathrm{M} \dagger, \mathrm{M} \times \mathrm{F}^{* *}, \mathrm{~F} \times \operatorname{Pr}^{* 4}$ \\
\hline Lactose, $\mathrm{g} / \mathrm{d}$ & 1,272 & 1,218 & 59.9 & 1,242 & 1,331 & 48.9 & NS \\
\hline Fat, $\mathrm{g} / \mathrm{kg}$ & 39 & 39 & 0.8 & 41 & 40 & 0.6 & $\operatorname{Cov}^{* * *}, \mathrm{M} \dagger$ \\
\hline Protein, g/kg & 31 & 31 & 0.4 & 32 & 31 & 0.5 & $\operatorname{Cov}^{* * *}, \operatorname{Pr} \dagger^{5}$ \\
\hline Lactose, $\mathrm{g} / \mathrm{kg}$ & 46 & 46 & 0.4 & 47 & 46 & 0.5 & NS \\
\hline
\end{tabular}

${ }^{1} \mathrm{Ll}=$ low-protein, low-fat ryegrass silage; $\mathrm{Lh}=$ low-protein, high-fat; $\mathrm{Hl}=$ high-protein, low-fat; Hh = highprotein, high-fat.

${ }^{2}$ Cow 1959 (Young-Lh) was dropped from the experiment, and 1599 (Mature-Hl) datum was deleted for this analysis due to very low production.

${ }^{3} \mathrm{Cov}=$ covariate (previous lactation, similar variable); $\mathrm{M}=$ maturity; $\mathrm{Pr}=$ protein; $\mathrm{F}=$ fat.

${ }^{4} \mathrm{~F} \times \mathrm{Pr}=\mathrm{Ll}=858, \mathrm{Hl}=820, \mathrm{Lh}=832, \mathrm{Hh}=877, \mathrm{SEM}(5 \%)=20.8 \mathrm{~g} / \mathrm{d}$.

${ }^{5} \mathrm{Pr}=$ low-protein $=31$, high-protein $=32 \mathrm{~g} / \mathrm{kg}$, SEM $(5 \%)=0.92$.

$\dagger P \leq 0.10 ; * P \leq 0.05 ; * * P \leq 0.01 ; * * * P \leq 0.001$. 
Table 6. Mean treatment effects on milk $\mathrm{N}$ fractions at 3 wk postcalving of cows fed with $\mathrm{Hh}, \mathrm{Hl}$, Lh, and $\mathrm{Ll}^{1}$ diets during the precalving period (values are covariate-adjusted means)

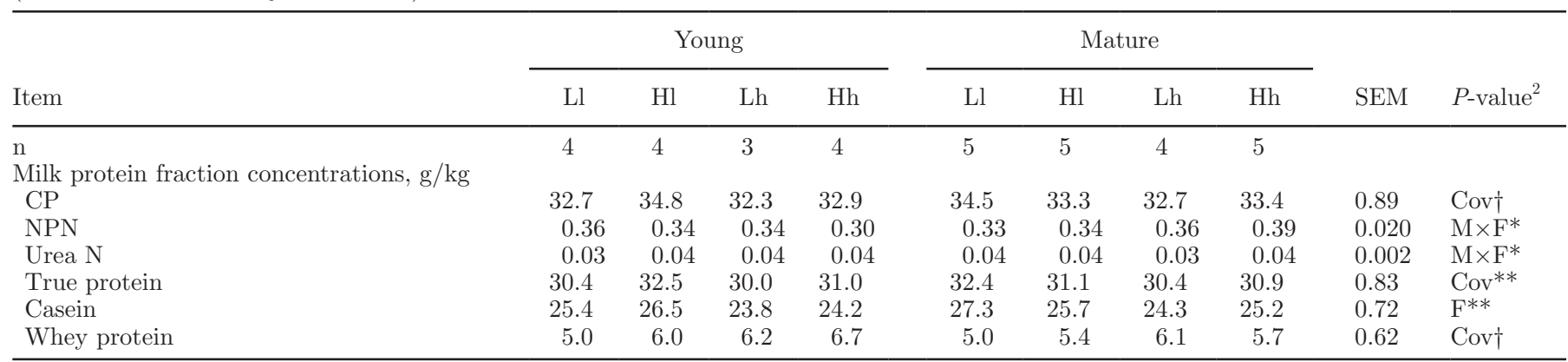

${ }^{1} \mathrm{Ll}=$ low-protein, low-fat ryegrass silage; $\mathrm{Lh}=$ low-protein, high-fat; $\mathrm{Hl}=$ high-protein, low-fat; $\mathrm{Hh}=$ high-protein, high-fat.

${ }^{2} \mathrm{Cov}=$ covariate (previous lactation, similar variable); $\mathrm{M}=$ maturity; $\mathrm{F}=$ fat.

$\dagger P \leq 0.10 ;{ }^{*} P \leq 0.05 ; * * P 0.01$.

authors (Kronfeld, 1982; Grummer, 1993; Grum et al., 1996). The higher incidence would, however, support the concerns expressed by Douglas et al. (2006) about the potential detrimental effects of allowing ad libitum access to diets containing moderate to high energy densities throughout the entire DP.

\section{Feed Characteristics and Intake}

Both silages used pre- and postcalving showed acceptable fermentation characteristics and were within the range of values commonly found in the United Kingdom (Haigh, 1996a,b). The ash content of Megalac was higher than manufacturer specifications because the ashing procedure used (combustion at $550^{\circ} \mathrm{C}$ ) could have retained $\mathrm{Ca}$ as $\mathrm{CaCO}_{3}$ instead of $\mathrm{CaO}$ (Dedman and Owen, 1962).

The greatest differences in DMI in the DP were between the 2 age groups as a reflection of BW differences; thus, as a proportion of BW, DMI recorded at the beginning of the experiment agreed with other reports (van Saun and Sniffen, 1996; Dewhurst et al., 2000). These results agree with studies that have shown that primigravid and even second-calving cows, as in this experiment, have lower DMI than multiparous cows (Grummer, 1998; Ingvartsen and Andersen, 2000) and, thus, should be considered separately from mature cows for diet formulation, as recognized by NRC (2001).

Table 7. Mean treatment effects on milk $\mathrm{N}$ fractions yields (g/d) at 3 and 8 wk postcalving of cows fed with $\mathrm{Hh}, \mathrm{Hl}, \mathrm{Lh}$, and $\mathrm{Ll}^{1}$ diets during the precalving period (values are covariate-adjusted means)

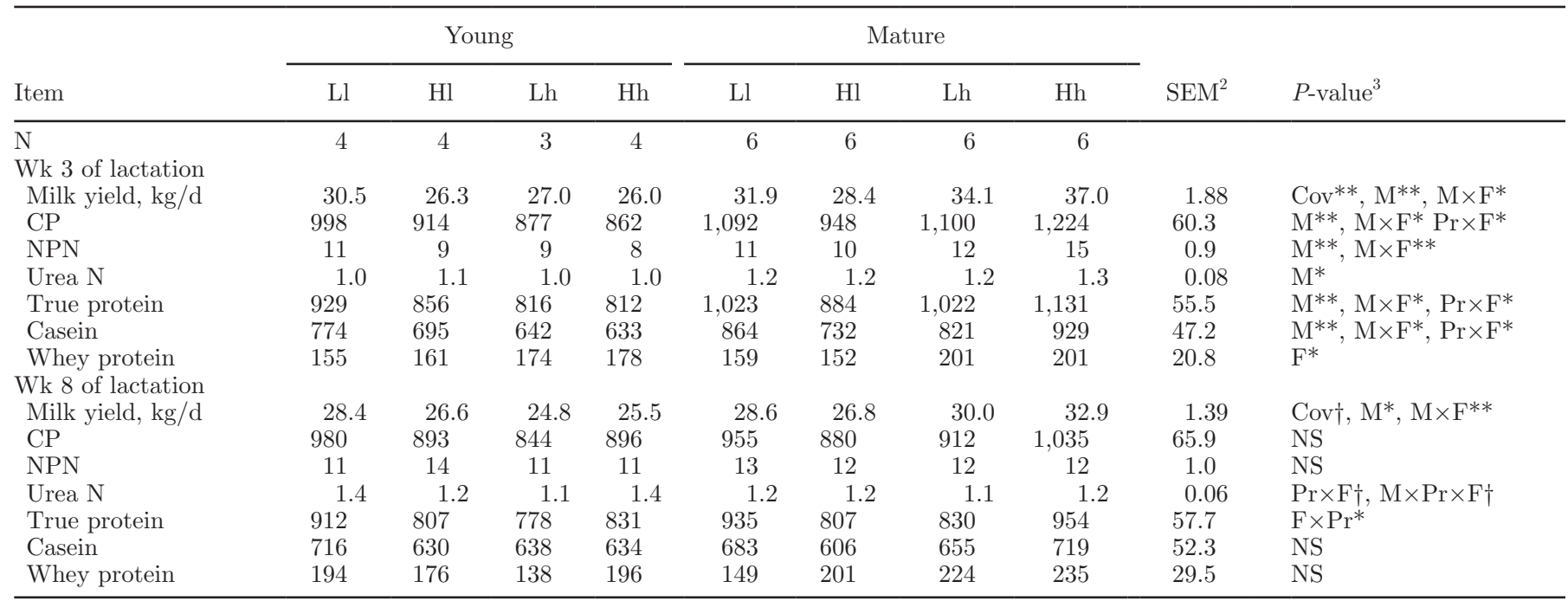

${ }^{1} \mathrm{Ll}=$ low-protein, low-fat ryegrass silage; $\mathrm{Lh}=$ low-protein, high-fat; $\mathrm{Hl}$ = high-protein, low-fat; Hh = high-protein, high-fat

${ }^{2}$ Standard error of the mean for $\mathrm{n}=6$.

${ }^{3} \mathrm{Cov}=$ covariate (previous lactation, similar variable); $\mathrm{M}=$ maturity $; \mathrm{Pr}=$ protein $\mathrm{F}=$ fat.

$\dagger P \leq 0.10 ;{ }^{*} P \leq 0.05 ;{ }^{* *} P \leq 0.01 ; * * * P \leq 0.001$. 
Inclusion of fat in dairy cow rations, despite the potential improvements in energy intake, has often been found to induce a reduction in feed intake in lactating dairy cows (Choi and Palmquist, 1996; Staples et al., 1998). In our study, a noticeable response in DMI during the DP was observed for CGM supplementation (which induced an increase in diet $\mathrm{CP}$ concentration from 143 to $170 \mathrm{~g} / \mathrm{kg}$ of $\mathrm{DM}$ ) in the cows fed with high fat concentrations. This was particularly significant for the mature cow group. In our experiment, the Hh ration was $19 \%$ higher in CP concentration than the Lh ration, which could have brought about a positive response in microbial activity due to the release of dietary AA in the rumen (Orskov, 1982; Dawson et al., 1988). Furthermore, voluntary intake increases could have been promoted by the increase in MP supply, something not frequently reported but previously observed in lactating dairy cows (Allen, 2000; Faverdin et al., 2003). Precalving DMI (average of wk -5 to -1 ) of young and mature cows offered the low-F rations was $1.9 \%$ of their BW, but within the mature group offered the high-F rations DMI increased from 1.8 (mature$\mathrm{Lh}$ ) to $2.2 \% \mathrm{BW}$ (mature-Hh) in association with PM supplementation. The typical DMI reduction during the DP as calving approaches constitutes a restriction in energy and nutrient inputs during a period of particularly high nutrient demands. The pattern of intake reduction showed, as in other reports, the DMI decline before the DP (Ingvartsen and Andersen, 2000) and the final drop during the last 3 wk of gestation (van Saun et al., 1993; NRC, 2001).

\section{Body Composition Characteristics}

All cows were in relatively poor condition at dry off (about 1.8 on a $0-5$ scale) in relation to targets reported in the literature [e.g., 2 to 3, Garnsworthy (1988) and Palmquist (1993); 2.5 to 3, van Saun and Sniffen (1996); 3, Mulvany (1977) and Moorby et al. (2002a)]. However, the cows in the current study recovered significant quantities of BCS after being dried off and achieved a maximum precalving BCS of 2.4 a few days before calving. The inclusion of fat in the precalving diet increased the maximum back fat thickness by a mean of about $1 \mathrm{~mm}$ in the mature cows (a mean of 4.54 vs. $3.53 \mathrm{~mm}$ for young cows, $\mathrm{SEM}=0.247$ ), and reduced the time interval between maximum BCS and back fat thickness and calving. These results suggest that fat supplementation during the DP improved the energy balance of mature cows and delayed the initiation of tissue mobilization before calving.

The depth of LD at the loin was measured as an estimate of labile body protein (Moorby et al., 2002a). All animals gained LD depth during the DP and started mobilization of LD before calving, in agreement with Moorby et al. (2002b). Maximum LD muscle depth increased significantly with cow maturity and Pr supplementation, with both diet and maturity producing different patterns of LD mobilization over the course of the experiment. This indicates that labile body protein can be increased by the provision of a protein supplement during the DP, and this would increase BCS as well, particularly for cows in poor body condition (Jaurena et al., 2005).

Cow maturity had widespread effects, as it was the significant main factor found to influence initial BCS and $\mathrm{BW}$, maximum BCS, and maximum LD depth. Response differences have been noted due to age at first calving (2 vs. 3 yr old, Dewhurst et al., 2002) and parity on lactation performance (Waltner et al., 1992; Dewhurst et al., 2002) and pattern of change of BCS (Waltner et al., 1992). Animals that calve for the first time at about 2 yr old are still growing during the first and second lactations, which was indicated in our study by differences in plasma somatotropin concentrations observed in this herd (data not shown), which could affect the partitioning of nutrients between fetal and maternal tissues. Differences may also exist in the response to DP nutrition between first-calving heifers and older cows (Robinson et al., 2004), which is probably a consequence of the same effect, and highlights the importance of managing young and older dry cows separately under commercial conditions.

Postpartum mobilization of body tissues was apparent through losses in BW and BCS. Changes in back fat thickness and in plasma concentrations of fatty acids and BHB (data not shown) indicate the mobilization of body fat, and losses of LD depth indicate concomitant body protein mobilization. Supplementation of the DP diet with CGM reduced the amount of LD lost and increased the minimum depth of LD measured during early lactation, agreeing with the results of Hutjens (1996) and Moorby et al. (2002b), respectively. Inclusion of fat in the DP ration did not affect the maximum LD depth before calving, but led to greater LD losses postpartum, particularly in the mature animals. This was likely due to the higher milk and protein yields observed from the mature cows offered high-fat DP rations and agrees with the hypothesis of Moorby et al. (2002b), that the availability of body nutrients to support milk production does not drive increased rate of milk synthesis. Further support for this is provided by changes in plasma prolactin concentrations among the animals in our study (data not shown).

The developing udder and conceptus together constitute an increasing proportion of BW gain as the animal approaches calving. No differences in udder volume were detected due to the experimental treat- 
ments (grand mean 38.5 L, SEM = 1.53). Although external noninvasive measurements associated with udder volume have proven to be effective in estimating udder weight (Dewhurst et al., 1993), it must be recognized that udder volume is a crude measurement of total tissue mass and does not provide information on the relative proportion of secretory tissue or cisternal volume (Dewhurst and Knight, 1993).

\section{Calf Birth Weight, Milk Composition, and Milk Yield}

Colostrum protein concentration was within the normal range (approximately 70 to $230 \mathrm{~g} / \mathrm{kg}$; Kehoe et al., 2007) expected for Holstein dairy cows. Likewise, as in previous reports (Tesfa et al., 1999; Santos et al., 2001), no association was found between colostrum composition and precalving diet or cow maturity and no differences in density, as reported by Robinson et al. (2009).

We noted limited effects of experimental treatment on milk composition over the first 20 wk of lactation. Milk protein concentration increased with the inclusion of the protein supplement in the DP diet, as previously noted for primiparous (van Saun et al., 1993; Santos et al., 1999) and multiparous (Moorby et al., 1996) Holstein dairy cows. However, other reports have failed to find any relationship between precalving $\mathrm{CP}$ intake and subsequent milk production or composition (Wu et al., 1997; Putnam and Varga, 1998; Huyler et al., 1999; Murphy, 1999), which could be associated with the protein concentration or quality of the control diets. Analysis of milk protein fraction concentrations at wk 3 and 8 of lactation found typical values for casein $\mathrm{N}$ and whey proteins concentrations, but NPN was slightly above the range 250 to $300 \mathrm{mg} / \mathrm{L}$ of milk assumed as normal (DePeters and Ferguson, 1992). Milk urea concentrations were within the normal range (DePeters and Ferguson, 1992), and did not exceed the threshold set for Holstein dairy cows fed according to requirements (Jonker et al., 1998) and RDP balance (Schepers and Meijer, 1998).

Several small but significant effects of treatments were observed among milk and milk component yields. Mature cows had higher concentrations of milk fat than young cows, and DP Pr supplementation increased milk protein concentrations. However, fat supplementation of the DP diet of the mature cows increased milk yield and protein yields, whereas no differences were detected for young cows. Perhaps the most notable result was the effect of CGM supplementation on milk protein yield in fat-supplemented animals; this was associated with differences in DP diet CP contents and intake. The results obtained from the sets of milk samples studied at wh 3 and 8 of lactation indicated that the positive effect of precalving dietary fat diminished as lactation progressed, as is expected if mobilization of body tissues is playing an important role in lactation (Garnsworthy, 1988; Holter et al., 1990).

\section{CONCLUSIONS}

Precalving supplementation of under-conditioned dry dairy cows with both fat and protein apparently improved body fat reserves and labile body protein and delayed body tissue mobilization, although differences were found between primiparous and multiparous cows. Precalving intakes of cows receiving the high-fat diets were increased by CGM supplementation, particularly for mature cows. Supplementation of the DP diet with protein also led to a significant increase in calf birth weight and a small increase in milk protein concentration over the first $20 \mathrm{wk}$ of the subsequent lactation; however, milk protein yield was only increased when the DP diet was also enriched with fat. Animal maturity was a significant factor in this experiment, as mature cows ate more in absolute terms because they were bigger, and therefore had a larger labile body protein pool than younger cows. Overall, differences in feed intake indicated that dry period management should consider younger second-calving cows as requiring diets with higher nutrient densities than older cows.

\section{ACKNOWLEDGMENTS}

The authors thank W. J. Fisher and R. Davies (Institute of Grassland and Environmental Research, Aberystwyth, UK) for their skillful assistance in managing and sampling the experimental herd. This work was funded by the UK Ministry of Agriculture, Fisheries and Food (now the Department for Environment, Food and Rural Affairs, UK), and G. Jaurena is grateful for scholarships provided by the British Council and "Fundación Antorchas (Argentina)" (Buenos Aires, Argentina).

\section{REFERENCES}

AFRC. 1993. Energy and protein requirements of ruminants. An advisory manual prepared by the AFRC technical committee on responses to nutrients prepared by the AFRC (Agricultural and Food Research Council) technical Committee on Responses to Nutrients. G. Alderman and B. R. Cottrill, ed. CAB International, Wallingford, UK.

Allen, M. S. 2000. Effects of diet on short-term regulation of feed intake by lactating dairy cattle. J. Dairy Sci. 83:1598-1624.

Beever, D. E. 2006. The impact of controlled nutrition during the dry period on dairy cow health, fertility and performance. Anim. Reprod. Sci. 96:212-226.

Bell, A. W. 1993. Pregnancy and fetal metabolism. Pages 405-431 in Quantitative Aspects of Ruminant Digestion and Metabolism. J. France, ed. CAB International, Wallingford, UK. 
Bell, A. W., R. Slepetis, and R. A. Ehrdardt. 1995. Growth and accretion of energy and protein in the gravid uterus during late pregnancy in Holstein cows. J. Dairy Sci. 78:1954-1961.

Choi, B. R., and D. L. Palmquist. 1996. High fat diets increase plasma cholecystokinin and pancreatic polypeptide, and decrease plasma insulin and feed intake in lactating cows. J. Nutr. 126:2913-2919.

Crowe, M. A. 2008. Resumption of ovarian cyclicity in post-partum beef and dairy cows. Reprod. Domest. Anim. 43(Suppl. 5):20-28.

Dawson, J. M., C. I. Bruce, P. J. Buttery, M. Gill, and D. E. Beever. 1988. Protein metabolism in the rumen of silage-fed steers: Effect of fishmeal supplementation. Br. J. Nutr. 60:339-353.

Dedman, A. J., and A. J. Owen. 1962. Calcium cyanamide synthesis. Part 4. The reaction $\mathrm{CaO}+\mathrm{CO}_{2}=\mathrm{CaCO}_{3}$. Trans. Faraday Soc. 58:2027-2035.

DePeters, E. J., and J. D. Ferguson. 1992. Non protein nitrogen and protein distribution in the milk of cows. J. Dairy Sci. 75:3192-3209.

Dewhurst, R. J., and C. H. Knight. 1993. An investigation of the changes in sites of milk storage in the bovine udder over 2 lactation cycles. Anim. Prod. 57:379-384.

Dewhurst, R. J., A. M. Mitton, and C. H. Knight. 1993. Calibration of polyurethane foam cating technique for estimating the weight of bovine udders. Pages 101-102 in Proc. Br. Society of Anim. Prod. Winter Meeting, Mar. 13-17, 1993, Scarborough, UK. British Society of Animal Science, Midlothian, UK.

Dewhurst, R. J., J. M. Moorby, M. S. Dhanoa, R. T. Evans, and W. J. Fisher. 2000. Effects of altering energy and protein supply to dry dairy cows. 1. Intake, body composition and milk production. J. Dairy Sci. 83:1782-1794.

Dewhurst, R. J., J. M. Moorby, M. S. Dhanoa, and W. J. Fisher. 2002 Effects of level of concentrate feeding during the second gestation of Holstein-Friesian dairy cows. 1. Feed intake and milk production. J. Dairy Sci. 85:169-177.

Douglas, G. N., T. R. Overton, H. G. Bateman Ii, H. M. Dann, and J. K. Drackley. 2006. Prepartal plane of nutrition, regardless of dietary energy source, affects periparturient metabolism and dry matter intake in Holstein cows. J. Dairy Sci. 89:2141-2157.

Drackley, J. K. 1999. Biology of dairy cows during the transition period: The final frontier? J. Dairy Sci. 82:2259-2273.

Faverdin, P., D. M'Hamed, and R. Verite. 2003. Effects of metabolizable protein on intake and milk production of dairy cows independent of effects on ruminal digestion. Anim. Sci. 76:137-146.

FIL-IDF. 1964. International Dairy Federation Standard. Vol. 29. FILIDF. International Dairy Federation, Brussels, Belgium.

Fronk, T. J., L. H. Schultz, and A. R. Hardie. 1980. Effect of dry period overconditioning on subsequent metabolic disorders and performance of dairy cows. J. Dairy Sci. 63:1080-1090.

Garnsworthy, P. C. 1988. The effect of energy reserves at calving on performance of dairy cows. Pages 157-169 in Nutrition and Lactation in the Dairy Cow. Vol. 1. P. C. Garnsworthy, ed. Butterworths, London, UK.

GenStat-Committee. 2000. Genstat for Windows, 5th ed. VSN International, Oxford, UK.

Grum, D. E., J. K. Drackley, R. S. Younker, D. W. LaCount, and J. J. Veenhuizen. 1996. Nutrition during the dry period and hepatic lipid metabolism of periparturient dairy cows. J. Dairy Sci. 79:1850-1864.

Grummer, R. R. 1993. Etiology of lipid-related metabolic disorders in periparturient dairy cows. J. Dairy Sci. 76:3882-3896.

Grummer, R. R. 1998. Transition cow energy, protein nutrition examined. Feedstuffs 70:11-13.

Haigh, P. M. 1996a. The effect of dry matter content and silage additives on the fermentation of bunker-made grass silage on commercial farms in England 1984-91. J. Agric. Eng. Res. 64:249-259.

Haigh, P. M. 1996b. The effect of dry matter content and silage additives on the fermentation of bunker-made grass silages on commercial farms in Wales 1987-93. J. Agric. Eng. Res. 64:261-270.

Holter, J. B., M. J. Slotnick, H. H. Hayes, C. K. Bozak, W. E. Urban, and M. L. McGilliard. 1990. Effect of prepartum dietary energy on condition score, postpartum energy, nitrogen partitions, and lactation production responses. J. Dairy Sci. 73:3502-3511.
Hutjens, M. F. 1996. Practical approaches to feeding the high producing cow. Anim. Feed Sci. Technol. 59:199-206.

Huyler, M. T., R. L. Kincaid, and D. F. Dostal. 1999. Metabolic and yield responses of multiparous Holstein cows to prepartum rumen undegradable protein. J. Dairy Sci. 82:527-536.

Ingvartsen, K. L., and J. B. Andersen. 2000. Integration of metabolism and intake regulation: A review focusing on periparturient animals. J. Dairy Sci. 83:1573-1597.

Jaurena, G. 2003. Effect of dry period protein nutrition on subsequent milk production from dairy cows. $\mathrm{PhD}$ thesis. Institute of $\mathrm{Ru}-$ ral Studies - Institute of Grassland and Environmental Research (IGER). University of Wales (Aberystwyth), Aberystwyth, UK.

Jaurena, G., J. M. Moorby, W. J. Fisher, and R. Cantet. 2005. Association of body weight, loin longissimus dorsi and backfat with body condition score in dry and lactating holstein dairy cows. Anim. Sci. 80:219-224.

Jonker, J. S., R. A. Kohn, and R. A. Erdman. 1998. Using milk urea nitrogen to predict nitrogen excretion and utilization efficiency in lactating dairy cows. J. Dairy Sci. 81:2681-2692.

Kehoe, S. I., B. M. Jayarao, and A. J. Heinrichs. 2007. A survey of bovine colostrum composition and colostrum management practices on Pennsylvania dairy farms. J. Dairy Sci. 90:4108-4116.

Kronfeld, D. S. 1982. Major metabolic determination of milk volume, mammary efficiency, and spontaneous ketosis in dairy cows. J. Dairy Sci. 65:2204-2212.

Mee, J. F. 2008. Prevalence and risk factors for dystocia in dairy cattle: A review. Vet. J. 176:93-101.

Moorby, J. M., R. J. Dewhurst, R. T. Evans, and W. J. Fisher. 2002a. Effects of level of concentrate feeding during the second gestation of Holstein-Friesian dairy cows. 2. Nitrogen balance and plasma metabolites. J. Dairy Sci. 85:178-189.

Moorby, J. M., R. J. Dewhurst, R. T. Evans, and W. J. Fisher. 2002b. Effects of varying the energy and protein supply to dry cows on high-forage systems. Livest. Prod. Sci. 76:125-136.

Moorby, J. M., R. J. Dewhurst, and S. Marsden. 1996. Effect of increasing digestible undegraded protein supply to dairy cows in late gestation on the yield and composition of milk during the subsequent lactation. Anim. Sci. 63:201-213.

Moorby, J. M., N. M. Ellis, and D. R. Davies. 2016. Assessment of dietary ratios of red clover and corn silages on milk production and milk quality in dairy cows. J. Dairy Sci. 99:7982-7992.

Mulvany, P. 1977. Dairy cow condition scoring. Paper No. 4468. No. Paper No. 4468. National Institute for Research in Dairying, Reading, UK.

Murphy, J. J. 1999. Effect of dry period protein feeding on post-partum milk production and composition. Livest. Prod. Sci. 57:169-179.

NRC. 2001. Nutrient Requirements of Dairy Cattle. 7th Rev. ed. Natl. Acad. Press, Washington, DC.

Orskov, E. R. 1982. Protein Nutrition in Ruminants. Academic Press, London, UK.

Otto, K. L., J. D. Ferguson, D. G. Fox, and C. J. Sniffen. 1991. Relationship between body condition score and composition of 9th to 11th rib tissue in Holstein dairy-cows. J. Dairy Sci. 74:852-859.

Palmquist, D. L. 1993. Meeting the energy needs of dairy cows during early lactation. Page 43 in Proc. Tri-State Dairy Nutrition Conference. Ohio State University, Michigan State Univ., and Purdue Univ., Ft. Wayne, IN. Michigan State University, East Lansing.

Prior, R. L., and D. B. Laster. 1979. Development of the bovine fetus. J. Anim. Sci. 48:1546-1553.

Putnam, D. E., and G. A. Varga. 1998. Protein density and its influence on metabolite concentration and nitrogen retention by Holstein cows in late gestation. J. Dairy Sci. 81:1608-1618.

Robinson, P. H., J. M. Moorby, M. Arana, and T. Graham. 2004. Effect of feeding a high- or low-rumen escape protein supplement to dry Holstein cows and heifers within 3 weeks of calving on their productive and reproductive performance in the subsequent lactation. Anim. Feed Sci. Technol. 114:43-57.

Robinson, P. H., J. M. Moorby, and D. D. Gisi. 2009. Colostrum production by primiparous and multiparous Holstein dairy cows and its usefulness as an estimator of full lactation milk yield. Livest. Sci. 125:323-325. 
Santos, J. E. P., E. J. DePeters, P. W. Jardon, and J. T. Huber. 1999. Effect of prepartum crude protein level on performance of primiparous Holstein cows. J. Dairy Sci. 82(Suppl. 1):120. (Abstr.).

Santos, J. E. P., E. J. DePeters, P. W. Jardon, and J. T. Huber 2001. Effect of prepartum dietary protein level on performance of primigravid and multiparous Holstein dairy cows. J. Dairy Sci. $84: 213-224$.

Schepers, A. J., and R. G. M. Meijer. 1998. Evaluation of the utilization of dietary nitrogen by dairy cows based on urea concentration in milk. J. Dairy Sci. 81:579-584.

Staples, C. R., J. M. Burke, and W. W. Thatcher. 1998. Influence of supplemental fats on reproductive tissues and performance of lactating cows. J. Dairy Sci. 81:856-871.

Studer, E. 1998. A veterinary perspective of on-farm evaluation of nutrition and reproduction. J. Dairy Sci. 81:872-876.

Tesfa, A. T., M. Tuori, L. Syrjala-Qvist, R. Poso, H. Saloniemi, K. Heinonen, K. Kivilahti, T. Saukko, and L. A. Lindberg. 1999. The influence of dry period feeding on liver fat and postpartum performance of dairy cows. Anim. Feed Sci. Technol. 76:275-295.
Tyrrell, H. F., and J. T. Reid. 1965. Prediction of the energy value of cow's milk. J. Dairy Sci. 48:1215-1223.

van Saun, R. J., S. C. Idleman, and C. J. Sniffen. 1993. Effect of undegradable protein amount fed prepartum on postpartum production in first lactation Holstein cows. J. Dairy Sci. 76:236-244.

van Saun, R. J., and C. J. Sniffen. 1996. Nutritional management of the pregnant dairy cow to optimise health, lactation and reproductive performance. Anim. Feed Sci. Technol. 59:13-26.

Waltner, S. S., J. P. McNamara, D. Brown, and J. K. Hillers. 1992. The validation of body condition score, fat cell size and deuterium oxide dilution as indirect body fat measures in lactating, Holstein dairy cattle. J. Dairy Sci. 74(Suppl. 1):252. (Abstr.).

Wu, Z., R. J. Fisher, C. E. Polan, and C. G. Schwab. 1997. Lactational performance of cows fed low or high ruminally undegradable protein prepartum and supplemental methionine and lysine postpartum. J. Dairy Sci. 80:722-729.

Zhu, W.-Y., M. K. Theodorou, A. C. Longland, B. B. Nielsen, J. Dijkstra, and A. P. J. Trinci. 1996. Growth and survival of anaerobic fungi in batch and continuous-flow cultures. Anaerobe 2:29-37. 